\title{
The role of murine leukemia virus glycosated Gag protein in virus replication
}

\author{
Hung Fan \\ From Frontiers of Retrovirology 2011 \\ Amsterdam, The Netherlands. 3-5 October 2011
}

Murine leukemia viruses (MuLVs) encode an alternate form of Gag protein in addition to the standard Gag precursor polyprotein, glycosylated Gag (glyco-gag or gPr80 $\left.{ }^{g a g}\right)$. gPr80 ${ }^{\text {gag }}$ contains additional amino-terminal peptides, and it is glycosylated. Until recently the function of gPr80 $80^{g a g}$ was unclear, but we have recently shown that gPr80 gag facilitates viral budding and release through lipid rafts. Glyco-gag mutant virus is less efficiently released from fibroblasts, mutant virus has lower cholesterol content (and higher buoyant density), and less Gag precursor polyprotein $\left(\mathrm{Pr}_{6} 5^{\mathrm{gag}}\right)$ is associated with detergent-resistant membranes in infected cells. The mechanism by which gPr80 ${ }^{g a g}$ facilitates virus release is under investigation. The N-terminal 88 amino acids of gPr $80^{g a g}$ are sufficient to enhance virus release, indicating that the Gag sequences on this protein are not required. Cellular La protein is involved in $\mathrm{gPr} 80^{\mathrm{gag}}$ function, since overexpression of La phenocopies $\mathrm{gPr} 80^{g a g}$ in facilitating virus release, and knockdown of La abrogates gPr80 ${ }^{\text {gag }}$ enhancement of virus release. MuLV glyco-gag can also facilitate release of HIV-1 particles from transfected cells, which suggests that these two viruses may share mechanisms for directing virus release through lipid rafts. gPr80 ${ }^{\text {gag }}$ also counteracts the murine APOBEC 3 restriction factor (mA3) since gPr80 ${ }^{g a g}$ mutant virus shows a defect for establishment of infection in wild-type mice, but not in mA3 knockout animals.

Submit your next manuscript to BioMed Central and take full advantage of:

- Convenient online submission

- Thorough peer review

- No space constraints or color figure charges

- Immediate publication on acceptance

- Inclusion in PubMed, CAS, Scopus and Google Scholar

- Research which is freely available for redistribution

\section{() Biomed Central}

\section{Biomed Central}

